\title{
PENGEMBANGAN MODUL FILSAFAT BAHASA
}

\author{
Sugeng Suryanto, \& Agoes Hendriyanto \\ STKIP PGRI Pacitan \\ Email: dugenk1956@yahoo.com \\ DOI: http://dx.doi.org/10.17509/bs_jpbsp.v17i1.6956
}

\begin{abstract}
Abstrak
Penelitian ini bertujuan untuk melakukan pengembangan modul pada mata kuliah Filsafat Bahasa di STKIP PGRI Pacitan yang dilaksanakan tahun pertama 2013/2014 dan tahun kedua 2015/2016. Tahapan pengembangan untuk tahun pertama 3 tahapan: identifikasi permasalahan, potensi masalah, dan desain modul filsafat bahasa. Hasil pengembangan untuk tahun pertama berupa desain modul “filsafat bahasa scientific berbasis nilai karakter jilid 1 dan 2" ISBN 978-979-1533-19-5 dan 978-9791533-18-8. Penelitian tahun kedua terdiri: validasi mahasiswa dan ahli, revisi modul, uji coba terbatas, revisi modul, uji coba luas, revisi modul, modul siap dicetak. Hasil validasi ahli nilai sebesar $89 \%$, angket respons mahasiswa nilai sebesar $88,6 \%$, skor rata-rata $88,8 \%$. Tahap selanjutnya uji coba secara terbatas menghasilkan thitung ( $\mathrm{t} 12=2,77, \mathrm{t} 13=7,89, \mathrm{t} 14=8,96, \mathrm{t} 23=2,88, \mathrm{t} 24=4,69$, $\mathrm{t} 34=2,79)$ lebih besar dari t tabel dengan nilai 2,021. Setelah uji terbatas simpulannya bahwa modul filsafat bahasa scientific berbasis nilai kearifan lokal sangat layak digunakan. Proses uji secara luas didapatkan hasil $\mathrm{t}$ hitung lebih besar ( $\mathrm{t} 56=2,77, \mathrm{t} 57=6,48$, dan $\mathrm{t} 67=2,29)$ dari t tabel 2,021. Modul filsafat bahasa scientific berbasis nilai kearifan lokal" layak digunakan, jilid 1 ISBN 978-60225829-3-3 dan jilid 2 ISBN 978-602-25829-3-4.
\end{abstract}

Kata kunci: modul, filsafat, bahasa, kearifan lokal

\section{THE DEVELOPMENT OF LANGUAGE PHILOSOPHY MODULE}

\begin{abstract}
This study aims to develop modules of course on the Language Philosophy in STKIP PGRI Pacitan. It held in the first year of 2013/2014 and the second year of 2015/2016. There are 3 phases of the development: problem identification, potential problems, and design of language philosophy modules. The result of the development in the first year are a module design of scientific language philosophy based on character values of Vol 1 and 2" ISBN 978-979-1533-19-5 and 978-979-153318-8. The second year study consisted of: student and expert validation, module revision, limited trial, module revision, extensive testing, module revision, print-ready module. Expert validation result was $89 \%$, student debriefing questionnaire was $88,6 \%$, mean score $88,8 \%$. The result of the next phase of limited trial based on counts table $(\mathrm{t} 12=2.77, \mathrm{t} 13=7.89, \mathrm{t} 14=8.96, \mathrm{t} 23=2.88, \mathrm{t} 24=4.69, \mathrm{t} 34=$ $2.79)$ is bigger thant-table with 2,021 probabilities. After a limited test, we conclude that the scientificlanguage philosophy module based on the value of local wisdom is very feasible to use. Test process is broadly obtained that $\mathrm{t}$-count table is bigger ( $\mathrm{t} 56=2.77$, $\mathrm{t} 57=6,48$, and $\mathrm{t} 67=2,29)$ than $\mathrm{t}$-table 2,021 . The scientific-language philosophy module based on the value of local wisdom "is worth to use, volumes 1 ISBN 978-602-25829-3-3 and volume 2 ISBN 978-602-25829-3-4.
\end{abstract}

Keywords: module, philosophy, language, local wisdom 


\section{PENDAHULUAN}

Modul merupakan sumber belajar yang direncanakan untuk mencapai kompetensi yang telah terdapat dalam suatu modul. Maksud tujuan pembelajaran dengan modul untuk memdahkan mahasiswa untuk belajar secara mandiri di kelas maupun di luar kelas dengan panduan modul. Pembelajaran dengan modul diharapkan kegiatan belajar mengajar di perguruan Tinggi tidak tergantung dari peran dosen sehingga dapat meningkatkan kemampuan berpikr kritisnya. Kegiatan belajar mengajarnya lebih berpusat pada mahasiswa untuk meningkatkan kompetensi mahasiswa.

Kompetensiadalah jenis pengetahuan yang peserta didik yang meliputi kegiatan: memperoleh, mengembangkan, belajar, menggunakan dan melupakan (Erton, 2007,p.1). Kompetensi sebagaimana diamanatkan dalam Keputusan Menteri Pendidikan Nasional Republik Indonesia nomor 45 tahun 2002 tentang kurikulum inti pasal 1 yang berkaitan dengan kompetensi merupakan seperangkat tindakan cerdas, penuh tanggung jawab yang dimiliki seseorang sebagai syarat untuk dianggap mampu oleh masyarakat dalam melaksanakan tugas di bidang pekerjaan tertentu. Oleh karena itu, peran dosen atau guru, masyarakat, mahasiswa serta sarana prasarana pendukung di sekolah menjadi faktor utama dalam pencapaian kompetensi terseut.

Hashimah, Yunus, dan Raper (2007), ada beberapa alasan mengapa guru tidak memiliki pengetahuan pedagogis; pertama, pendekatan pengajaran yang digunakan di kelas menunjukkan inkonsistensi antara tujuan kurikulum dan pola interaksi kelas yang sebenarnya. Inkonsistensi ini mempengaruhi pelaksanaan kurikulum sebagaimana dimaksud oleh Departemen Pendidikan. Kedua, studi tentang mengajar dan belajar ilmu mengungkapkan bahwa prestasi akademik siswa adalah prioritas utama hasil guru dimaksudkan. Dengan demikian, guru mengabaikan hasil proses belajar. Ketiga, ada perbedaan antara peran guru menganggap di kelas mereka dapat melakukan peran mereka inginkan.

Kegiatan belajar dengan modul diharapkan tumbuh sikap kemandirian mahasiswa khususnya program Studi Pendidikan Bahasa dan Sastra Indonesia sehingga kompetensi berbahasa dan berpikir kritis akan mengalami suatu peningkatan. Sehingga peran dosen tidak dominan dalam pembelajaran menggunakan modul. Dosen pengampu mata kuliah di program studi pendidikan bahasa dan sastra Indonesia perlu memiliki pemahaman yang komprehensif tentang apa kompetensi dan keahlian dalam pengajaran bahasa terdiri dari aspek: keterampilan, pengetahuan, nilai-nilai, sikap dan tujuan yang direncanakan dan bagaimana yang tersebut di atas dapat diperoleh (Richards, 2010,p. 101). Aspek keterampilan tersebut harus dituliskan dan dilaksanakan sebagai kompetensi yang ingin diwujudkan dalam setiap kegiatan pembelajaran.

Modul dapat membantu mahasiswa dalam kegiatan belajar secara mandiri di rumah sebagai bahan dalam melakukan kegiatan diskusi kelas dalam mata kuliah filsafat bahasa. Filsafat bahasa yang merupakan mata kuliah keahlian dan menjadi dasar bagi mahasiswa pedidikan bahasa dan sastra sebagai dasar kajian analisis penelitian bahasa dan astra Indonesia. Filsafat bahasa akan mengajarkan kepada mahasiswa untuk berpikir kritis berdasarkan tahapan ilmiah yang telah direncanakan untuk menghasilkan suatu simpulan. Untuk mencapai kompetensi tersebut kegiatan belajar mengajar filsafat bahasa salah satunya dengan menyediakan sumber belajar bagi mahasiswa berupa modul filsafat bahasa. Modul filsafat bahasa yang direncanakan oleh dosen pendidikan bahasa dan sastra Indonesia harus kita sesuaikan dengan kondisi terkini. Perencanaan dan pengembangan materi dalam setiap modul harus disesuaikan dengan kondisi terkini dan kompetensi yang ingin dicapat. Materi modul harus dimulai dari hal yang sifatnya 
sederhana ke hal yang sifatnya kompleks.

Dengan demikian pengembangan modul harus melalui beberapa tahapan dan perencanaan dengan maksud dan tujuan untuk mencetak pendidik bahasa dan sastra Indonesia yang profesional yang mempunyai kompetensi pedagogi, kompetensi keahlian, dan kompetensi sosial yang tinggi. Pengembangan modul juga harus disesuaikan dengan visi program studi pendidikan bahasa dan sastra Indonesia yang mempunyai visi menciptakan tenaga pendidik yang profesional, menciptakan wirausaha baru yang berbasis bahasa dan satra Indonesia. Untuk mewujudkan hal tersebut mahasiswa harus dibekali ilmu filsafat bahasa dengan pemikiran yang mendalam dengan berbagai tahapan pemikiran yang harus dilakukan untuk menjawab setiap persoalan baik yang berhubungan dengan bahasa dan sastra Indonesia maupun bidang lainnya yang relefan. Berdasarkan uraian di atas artikel ini mempunyai tujuan untuk mengembangkan modul filsafat bahasa dengan menggunakan metode penelitian pengembangan Research and Development (R \& D). Pengembangan modul filsafat bahasa dengan scientific merupakan jawaban untuk menjawab tuntutan mahasiswa yang berkaitan dengan materi ajar.

\section{METODE}

Penelitian ini menggunakan metode penelitian dan pengembangan (R\&D). Penelitian ini dilaksanakan selama 2 tahun. Kegiatan tahun pertama di antaranya sebagai berikut: (1) menemukan potensi dan masalah, melalui studi literatur filsafat bahasa dan observasi pembelajaran filsafat bahasa tahun sebelumnya (define), (2) pengumpulan data dilakukan dengan (pembelajaran mata kuliah filsafat bahasa dengan buku filsafat bahasa yang akan dikembangkan, referensi dari beberapa buku filsafat bahasa, kurikulum KKNI, jurnal penelitian) didokumentasikan dalam bentuk file ataupun catatan penelitian; dan (3) desain modul filsafat bahasa scientific dengan membuat draf modul yang didasarkan dari data yang telah berhasil dikumpulkan atau dalam proses kegiatan pembelajaran filsafat bahasa. Desain draf modul filsafat bahasa merupakan salah satu hasil luaran penelitian berupa modul "Filsafat Bahasa dalam Scientififc Berbasis Nilai Karakter jilid I dan II" ber-ISBN 978979-1533-19-5 jilid 1 dan 978-979-1533-18-8 jilid 2.

Sedangkan penelitian pengembangan tahun kedua draf atau desain modul yang telah berbentuk modul tersebut di atas masih memerlukan proses refisi untuk menyempurnakan modul melalui beberapa tahapan lagi. Penelitian pengembangan untuk tahun kedua masih memerlukan beberapa tahapan kegiatan penelitian sebagai berikut; 1) validasi ahli dan mahasiswa, 2) proses refisi, 3) uji coba terbatas, 4) proses refisi, 5) uji coba secara luas, 6) refsisi, 7) produk masal.

Obyek dari penelitian pengembangan ini mahasiswa semester 2 di Sekolah Tinggi Keguruan dan Ilmu Pendidikan PGRI Pacitan pada program studi pendidikan bahasa dan Sastra Indonesia tahun 2014/2015 dan 2015/2016 Teknik pengumpulan data yang digunakan dalam penelitian ini ialah: 1) teknik wawancara dilakukan dengan melakukan wawancara kepada dosen pengampu dan mahasiswa untuk memperoleh data dari informan tentang proses pembelajaran; 2) observasi langsung dipusatkan pada proses pembelajaran, 3) tes angket kepribadian, 4) tes lisan, 5) tes tulis; dan 6) analisis dokumen yang berhubungan dengan modul filsafat bahasa serta metode scientific. Penyusunan draf modul filsafat bahasa menganalisa buku filsafat bahasa yang mempunyai relevansi dari ahli filsafat bahasa dan pembelajaran.

Teknik penialaian menggunakan teknik portofolio. Portofolio merupakan kumpulan kerja mahasiswa yang dikumpulkan secara sistematis selama periode waktu tertentu (Ormrod, 2008: 341). Portofolio menunjuk pada sekumpulan karya mahasiswa yang berwujud karya verbal yang 
yang terdiri dari berbagai jenis tulisan yang berasal dari berbagai kompetensi bahasa (menulis, membaca, menyimak,

$$
\mathrm{t}=\frac{\left(\overline{\mathrm{X}_{1}}-\overline{\mathrm{X}_{2}}\right)}{\mathrm{s}_{\mathrm{p}} / \sqrt{\frac{1+1}{\mathrm{n}_{1}}+\frac{1}{\mathrm{n}_{2}}}}
$$

\section{HASIL DAN PEMBAHASAN}

\section{Pengembangan Modul Filsafat Bahasa} Tahun Pertama

Modul Filsafat Bahasa dan Metode Scientific merupakan bagian yang penting dalam proses pembelajaran Filsafat Bahasa pada Program Studi Pendidikan Bahasa dan Sastra Indonesia dalam meningkatkan kompetensi mahasiswa. Pengembangan modul filsafat bahasa untuk tahun pertama meliputi kegiatan sebagai berikut: potensi dan observasi masalah, pengumpulan data yang dilakukan dengan melakukan kegiatan pembelajaran dengan menggunakan draf modul yang akan dikembangkan, dan membuat draf atau desain modul filsafat bahasa.

Tahap pengembangan modul untuk tahap pertama menemukan potensi dan masalah yang sangat berhubungan dengan mata kuliah filsafat bahasa, dosen, dan berbicara) (Nurgiyantoro, 2010: 445). Data yang telah didapatkan dianalisis dengan uji t. Rumus t sebagai berikut.

$$
\begin{aligned}
\overline{\mathrm{X}}= & \text { Nilai rata-rata } \\
\mathrm{S}_{\mathrm{p}}= & \text { Standar deviasi } \\
& \text { gabungan } \\
\mathrm{n}= & \text { Jumlah sampel } \\
& \text { penelitian } \\
\mathrm{db}= & \left(\mathrm{n}_{1}+\mathrm{n}_{2}-2\right)
\end{aligned}
$$

karakteristik mahasiswa, dan sarana dan prasarana pendukung kegiatan pembelajaran filsafat bahasa. pembelajaran harus disesuaikan dengan karakteristik peserta didik. Peneliti dalam perencanaan dalam proses mengembangkan modul (bahan belajar mandiri) harus cermat dan teliti hal ini berkaitan dengan mutu modul yang akan dihasilkan. Wena (2010:230) mengatakan bahwa modul merupakan suatu paket pembelajaran yang berisi satu unit konsep tunggal. Paket pembelajaran mempunyai pengertian bahwa kompetensi, materi, latihan, dan simpulan merupakan satu kesatuan yang tidak boleh dipisahkan. Untuk mencapai komptensi berpikir kritis dan bahasa mahasiswa harus menyelesaikan seluruh materi yang terdapat dalam modul. Untuk lebih jelasnya dapat dilihat dalam tabel 1 berikut ini.

Tabel 1. Tahapan penelitian pengembangan modul tahun pertama

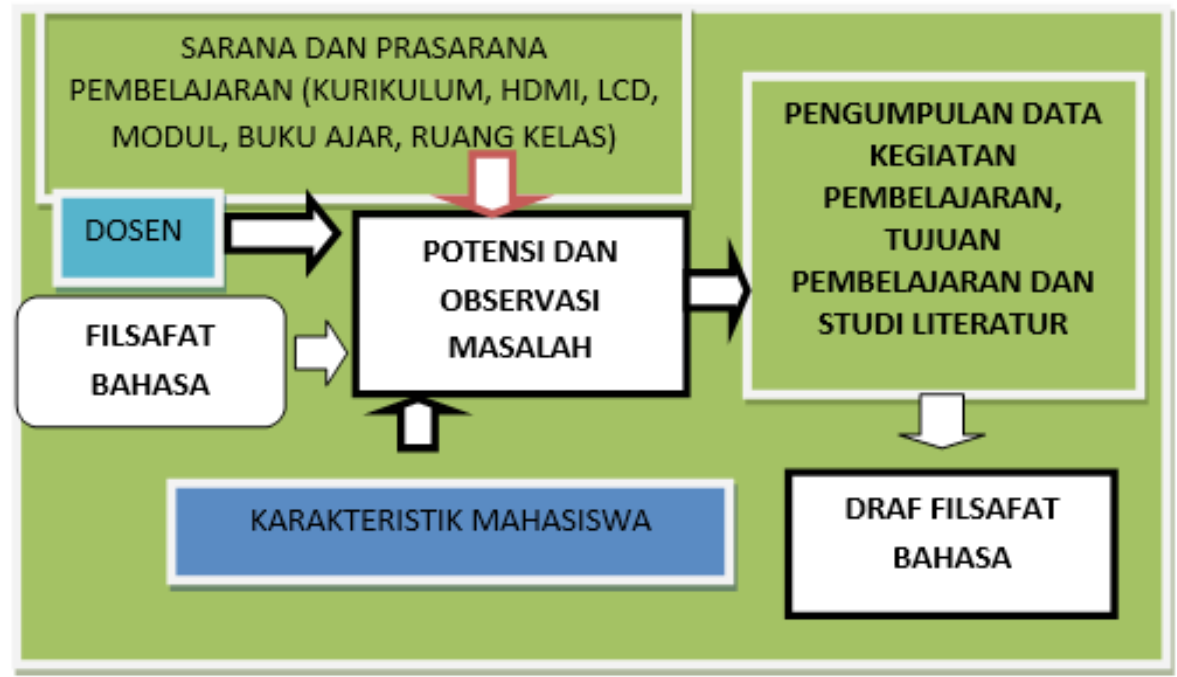


Purwanto, dan Suharto (2007,p.10) menyebutkan ada 3 cara untuk mengembangkan modul pembelajaran, yakni dengan cara adaptasi, kompilasi, dan menulis sendiri. Dengan kompetensi yang dimiliki oleh peneliti, cara kompilasi lebih dipilih untuk mengembangkan produk modul pembelajaran dengan memanfaatkan bahan-bahan seperti buku, artikel, dan jurnal ilmiah baik cetak atau noncetak.

Permasalahan yang berkaitan dengan karakteristik mahasiswa antara lain: kemampuan akademik individu, karakteristik fisik, kemampuan kerja kelompok, motivasi belajar, latar belakang ekonomi dan sosial, pengalaman belajarsebelumnya. Karakteristik mahasiswa perlu diketahui untuk menyusun kompetensi, materi, kegiatan belajar, evaluasi dalam modul yang sesuai dengan kemampuan akademiknya. Dalam proses dari merancang modul, kuncinya adalah untuk menjalin hubungan mendidik suara dan logis antara pelajar kebutuhan, tujuan, hasil belajar, sumber daya, belajar dan mengajar strategi, kriteria penilaian dan evaluasi (Donnelly \& Fitzmaurice, 2005,p. 100).

Peneliti juga harus merumuskan tujuan pembelajaran khusus atau kompetensi yang mengacu pada KKNI 2013. Seperti yang telah diuraikan di atas sumber referansi yang relefan dengan tujuan pembelajaran khusus yaitu meningkatkan kompetensi berpikir kritis yang memerlukan sebuah materi modul yang berhubungan dengan permasalahan yang harus dipecahkan bersama dalam kegiatan belajar mengajar. Peneliti juga harus mempertimbangkan keberadaan sarana dan prasarana di kampus sebagai strategi dalam memilih media yang akan digunakan. Kurikulum acuan dalam program studi Pendidikan Bahasa dan sastra Indonesia juga harus menjadi pertimbangan. Pembelajaran menggunakan modul, media sebagai pendukung dalam belajar dengan modul tetap diperlukan, seperti misalnya LCD, televisi HDMI, audio, film, ataupun media cetak tulis maupun tidak tulis, Media tersebut digunakan untuk mendukung pembelajaran melalui penggunaan modul, khususnya untuk memperkuat pembelajaran yang memerlukan praktek.

Analisis materi dilakukan dengan cara mengidentifikasi materi utama yang perlu diajarkan, mengumpulkan dan memilih materi yang relevan, dan menyusunnya kembali secara sistematis. Analisis materi ini peneliti mengumpulkan sebanyak mungkin buku referensi yang berhubungan dengan mata kuliah filsafat bahasa. Mengelompokkan dan mengklasifikasikan urutan materi tiap modul yang akan digunakan dalam setiap kegiatan belajar di kelas untuk mencapai kompetensi yang telah dirumuskan. Sebelum menulis bahan ajar, tujuan pembelajaran dan kompetensi yang hendak diajarkan perlu dirumuskan terlebih dahulu untuk membatasi peneliti supaya tidak menyimpang dari tujuan semula pada saat mereka sedang menulis modul.

Santyasa (2009) kegiatan yang dilakukan dalam pengembangan modul meliputi: 1) tahap pertama, analisis tujuan dan karakteristik mata kuliah / bidang studi; 2) tahap kedua, analisis sumber belajar; 3) tahap ketiga analisis karakteristik mahasiswa; 4) tahap keempat menetapkan sasaran dan isi pembelajaran; 5) tahap kelima menetapkan strategi pengorganisasian isi pembelajaran; 6) tahap keenam menetapkan strategi penyampaian isi pembelajaran; 7) tahap ketujuh, menetapkan strategi pengelolaan pembelajaran; dan 8) pengembangan prosedur pengukuran hasil pembelajaran.

Kegiatan pertama dalam pegembangan modul filsafat bahasa yaitu dengan melakukan analisis tujuan dan karakteristik mata kuliah filsafat bahasa termasuk dalam mata kuliah keahlian. Mata kuliah filsafat bahasa merupakan mata kuliah keahlian untuk proses berpikir dengan berdasarkan fakta yang ada. Pembelajaran mata kuliah ini difokuskan pada peningatan kemampuan berpikir kritis mahasiswa terhadap persoalan yang dihadapinya. Mata kuliah ini banyak 
kuliah ini banyak mengandung teori dan sulit dipahami oleh mahasiswa. Berdasarkan tahap pertama ini peneliti mengetahui karakteristik mata kuliah filsafat bahasa sebagai dasar dalam menyusun draf modul.

Kegiatan kedua yaitu dengan melakukan analisis dari berbagai sumber buku filsafat bahasa. Peneliti membaca berbagai sumber buku referensi filsafat bahasa dengan mencatat dibuku catatan penelitian setiap tema yang dapat dimasukan dalam pembelajaran modul filsafat bahasa. Proses ini memakan waktu yang agak lama karena peneliti membaca sumber yang didapatkan baik dari perpustakaan, toko buku maupun hasil dari internet. Hasil dari analiais sumber rujukan tersebut peneliti jadikan satu bendel yang akan digunakan untuk proses membuat draf modul.

Kegiatan ketiga peneliti menganalisis karakteristik mahasiswa khususunya program Studi Pendidikan Bahasa dan Sastra Indonesia tahun ajaran ganjil 2014/2015. Mahasiswa untuk latar belakang pendidikan sebelumya ada yang berasal dari SMA, SMK, MA baik negeri dan Swasta. Latar belakang sosial budaya mahasiswa menjadi pertimbangan tersendiri bagi peneliti dalam penyusunan draf modul filsafat bahasa. Jumlah mahasiswa dalam satu kelas juga menjadi pertimbangan peneliti normal ssatu kelas terdiri dari 20-25 mahasiswa lebih dari jumlah tersebut dosen atau pengajar sangat sulit untuk menguasai kelas yang jumlah mahasiswanya banyak.

Kegiatan analisis kebutuhan ini kami lakukan dengan melakukan kegiatan pendahuluan dengan melakukan pre test yang berhubungan dengan materi filsafat bahasa serta melakukan wawancara kepada mahasiswa yang telah mengambil mata kuliah filsafat bahasa berkaitan dengan tema yang paling diminati dan tema yang tidak disukai. Dengan tema dan topik yang disukai mahasiswa peneliti berharap penyusunan draf modul ini akan meningkatkan motivasi mahasiswa untuk mempelajari filsafat bahasa yang sementara ini menjadi mata kuliah yang tidak disukai mahasiswa program studi pendidikan bahasa dan sastra Indonesia

Kegiatan keempat menentukan sasaran atau sering disebut dengan standar kompetensi yang akan dicapai dalam pembelajaran filsafat bahasa. Standar kompensi tersebut akan dijabarkan dalam setiap modul. Untuk standar kompetensi peneliti sesuaikan dengan KKNI 2013 dengan memasukan metode scientific dalam membuat sub modul dengan melalui suatu tahapan ilmiah sampai pada kegiatan sub modul simpulan. Standar kompetensi ini akan sangat berhubungan dengan metode pengajaran yang dapat digunakan untuk mencapai standar kompetensi.

Kegiatan kelima sangat penting sekali yang berkaitan sekali dengan metode atau teknik pembelajaran yang paling efektif untuk mencapai standar kompetensi dan materi modul. Sedangkan tahapan keenam sampai ketujuh sangat berkaitan dengan materi mata kuliah yang dapat digunakan untuk mencapai tujuan yang terdapat dalam standar kompetensi. Selain itu juga pengorganisasian isi dan diakhiri dengan simpulan dan evaluasi sebagai langkah untuk menguji kemampuan mahasiswa setelah mempelajari modul yang disesuaikan dengan materi, standar kompetensi. Ketujuh kegiatan tersebut merupakan kegiatan penelitian pengembangan yang masih dalam tahapan pertama yaitu potensi dan observasi masalah.

Pada prinsipnya untuk tahapan pertama penelitian pengambangan modul filsafat bahasa yang menjadi prinsip dasar dalam keselarasan konstruktif adalah bahwa sistem mengajar yang baik merupakan hasil dari metode pengajaran dan penilaian terhadap kegiatan pembelajaran yang digunakan yang tercantum dalam tujuan sehingga semua aspek dari sistem ini adalah sesuai dalam mendukung belajar siswa yang sesuai (Biggs 1999,p.25). Donnelly dan Fitzmaurice (2005,p.105) menyatakan bahwa terdapat tiga unsur yang terlibat dalam proses konstruktif penyelarasan modul: 
pertama, mendefinisikan hasil pembelajaran; kedua, memilih pembelajaran dan metode pengajaran yang dapat menyebabkan pencapaian hasil; dan ketiga, menilai hasil belajar siswa.

Tahapan kedua yaitu meliputi kegiatan pengumpulan data yang dicatat, didokumentasikan sebagai modal yang penting bagi penyusunan draf desain modul filsafat bahasa. Tahapan kedua ini peneliti lakukan secara langsung dengan uji coba draf secara langsung digunakan dalam kegiatan belajar mengajar filsafat bahasa semester ganjil 2014/2015. Peneliti akan mencatat penemuan, perubahan, dan refisi draf modul filsafat bahasa pada saat kegiatan pembelajaran berlangsung. Peneliti secara langsung melakukan perubahan draf untuk meminimalkan kesalahan dalam menginterpretasikan permaslahan selama kegiatan pembelajaran dengan menggunakan draf modul yang telah digandakan dan digunakan oleh semua mahasiswa dalam kelas.

Selain itu juga peneliti melakukan kegiatan mencatat dan mengumpulkan datadata yang relefan dengan pengembangan modul filsafat bahasa. Penemuan selama proses pembelajaran berlangsung yang berhasil peneliti kumpulkan kemudian diketik dengan membuat draf modul filsafat yang baru. Selanjutnya draf tiap modul tersebut setidaknya harus memuat standar komptensi, kegiatan belajar, materi, evaluasi dan simpulan. Setiap 3 kali pertemuan untuk tiap modul yang berhasil peneliti refisi dilakukan uji dengan membuat pertanyaan evaluasi berhubungan dengan materi yang telah diselesaikan. Peneliti memerlukan kegiatan tersebut untuk mengetahui efektifitas draf modul tersebut dalam rangka mencapai standar kompetensi yang telah ditetapkan dalam tiap modul.

Setelah peneliti bersama dosen pengampu melakukan kegiatan uji draf di kelas 4 kali. Berdasarkan hasil uji coba draf di kelas kesepuluh modul yang terdapat dalam tabel 1 dengan jumlah 2 sks sangat berat mencapai kompetensi yang ingin diharapkan dalam kesepuluh modul. Mahasiswa dalam kegiatan 14 kali pertemuan tidak mungkin 10 modul tersebut dapat terselesaikan dengan baik. Minimal 3 kali pertemuan untuk dapat membaca, memahami, dan mengerjakan evaluasi dengan benar dalam setiap modul. Apalagi mata kuliah filsafat bahasa merupakan mata kuliah keahlian yang sangat penting untuk peningkatan kemampuan berpikir kritis mahasiswa.

Ketika membaca sebuah modul misalnya, tentu akan berusaha untuk memahami modul tersebut. Dalam proses demikian sebenarnya secara tidak langsung telah melakukan penilaian terhadap isi modul tersebut. Kemudian pada akhir pembelajaran akan didapatkan sebuah penilaian dari peneliti, dosen, dan mahasiswa dengan kriteria penilaian sukar, tidak begitu sukar, mudah atau mungkin terlalu mudah untuk dipahami. Kemudian temuan selama pembelajaran berlangsung peneliti catat dan didokumentasikan sebagai bahan dalam refisi draf modul filsafat bahasa.

Berdasarkan masukan dalam kegiatan pembelajaran di kelas peneliti melakukan kegiatan refisi draf modul filsafat bahasa menjadi 2 jilid sebagai berikut: draf modul 1 sampai modul 5 merupakan buku jilid 1 Filsafat Bahasa dengan scientific berbasis Pendidikan karakter; dan draf modul 6 sampai modul 10 merupakan bagian dari draf buku jilid 2 Filsafat Bahasa dengan scientific berbasis Pendidikan Karakter.

Berdasarkan tabel 2 untuk Jilid pertama terdiri dari 5 modul sebagai berikut: Modul Pertama, dengan "Judul tantangan bahasa dalam era globalisasi" terdiri dari sub modul (pendahuluan, tantangan bahasa, peranan bahasa ibu yang berisi tentang kajian teori dari beberapa ahli dan ditambahkan hasil dari penelitian, simpulan, evaluasi, dan formatif. Modul kedua, "filsafat bahasa dalam pembelajaran" terdiri dari beberapa sub modul yang meliputi: pendahuluan, 
filsafat bahasa, tokoh filsafat bahasa, dasar penalaran dalam logika, sejarah logika, filsafat bahasa dalam pembelajaran bahasa, logika sebagai matematika murni, kegunaan filsafat bahasa dalam pendekatan scientific, logika, macam-macam logika, kesalahan pendidikan karakter, simpulan, evaluasi, atau kesesatan, simpulan, evaluasi, dan dan formatif. Modul ketiga, "Sejarah formatif. Modul kelima, tentang "Bahasa Filsafat Bahasa" terdiri dari sub modul: dan Filsafat Bahasa" yang terdiri dari perkembangan filsafat bahasa, filsafat bahasa beberapa topik seperti: pengertian bahasa, jaman Yunani, filsafat bahasa jaman Romawi, fungsi bahasa, bahasa menurut Ferdinand de filsafat bahasa jaman pertengahan, filsafat Sausure, bahasa menurut Noam Chomsky, bahasa jaman modern, simpulan, evaluasi, serta hubungan antara filsafat dan bahasa, dan formatif. Modul keempat, "Logika dan simpulan, evaluasi, dan formatif.

Penalaran" terdiri dari: pengertian logika,

Tabel 2: Desain filsafat bahasa dalam scientific berbasis pendidikan karakter

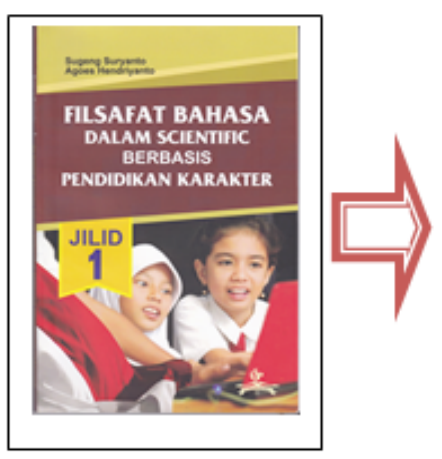

Modul 1 Tantangan bahasa dalam pusaran globalisasi (pendahuluan, tantangan bahasa, peranan bahasa, simpulan dan evaluasi

Modul 2 Filsafat Bahasa dalam Pembelajaran (Pendahuuan, Filsafat bahasa, Tokoh Filsafat Bahasa, Filsafat Bahasa dalam Pembelajaran, Simpulan, Evaluasi, formatif)

Modul 3 Sejarah Kajian Filsafat Bahasa (Pendahuluan, Perkembangan filsafat bahasa, Filsafat bahasa jaman Yunani, Romawi, Simpulan, Evaluasi, formatif).

Modul 4 Logika dan Penalaran (Pendahuluan, Pengertian Logika, Sejarah Logika, Kegunaan Logika, Simpulan, evaluasi, formatif).

Modul 5 Bahasa dan Filsafat bahasa (Pendahuluan, Pengertian Bahasa, Fungsi Bahasa, Strukturalisme, Gramatikal, Simpulan, Evaluasi, Formatif)

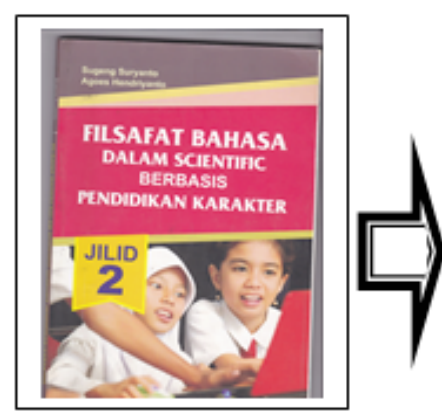

Modul 1 Makna Bahasa (pendahuluan, teori makna, perkembangan jenis kata, pengertian makna, simpulan, evaluasi, dan formatif.

Modul 2 Filsafat Analitik (Pendahuluan, Filsafat Analitik, George Edward Moore, Pemikiran George Edward Moore terhadap Filsafat Bahasa, Naturalisme, Kesalahan Naturalistik, simpulan, evaluasi, dan formatif).

Modul 3 Atomisme Logis Bertrand Russel (Pendahuluan, Atomisme Logis, Prinsip Kesesuaian Bertrand Russel, Struktur Proposisi Bertrand Russel, Kelemahan Teori Bertrand Russel, simpulan, evaluasi, dan formatif).

Modul 4 Atomisme Logis Wittgenstein (Pendahuluan, Pemikiran Wittgenstein I, Permainan Bahasa, kelemahan dari pemikiran Wittgenstein, simpulan, evaluasi, formatif).

Modul 5 Positivisme Logis Alfred Jules Ayer (Pendahuluan, Positivisme Logis, positivisme Alfred Jules Ayer, kritik Positivisme Alfred Jules Ayer, simpulan, evaluasi, dan formatif). 
Seperti yang telah dijelaskan di atas dalam modul kelima ini mahasiswa dihadapkan dari 2 pandangan yang berbeda tentang bahasa yaitu Ferdinand de Sausure dan Noam Chomsky yang memandang bahasa dari sudut yang berbeda. Ferdinand de Sausure memiliki kecenderungan untuk memahami bahasa dari struktur pembentuk bahasa (fonem, morfem, frasa, klausa, dan wacana) serta ilmu yang mendukungnya seperti (fonologi, morfologi, sintaksis, dan semantik). Tetapi Noam Chomsky mempelajari bahasa dari fungsi bahasa sebagaai alaat komunikasi sehingga dari pemikiran Chomsky ada teori competence, performance, diakronik, sinkronik dan sebagainya. Pada modul kelima ini mahasiswa dihadapkan dalam 2 pemikiran tentang bahasa yang berbeda sudut pandangnya. Oleh karena itu dalam ilmu bahasa sangat memerlukan sekali adanya kemampuan berpikir ilmiah dengan melalui beberapa tahapan sebelum mengambil suatu simpulan.

Sedangkan draf modul jilid kedua terdiri dari 5 modul yang terdiri dari: Modul Pertama "Makna Bahasa" terdiri dari: pendahuluan, teori makna, perkembangan jenis kata dalam filsafat bahasa, serta pengertian makna, simpulan, evaluasi, dan formatif. Modul Kedua "Filsafat Analitik" terdiri dari: filsafat analitik, George Edward Moore, pemikiran George Edward Moore terhadap filsafat bahasa, naturalisme etis George Edward Moore, serta kesalahan naturalistik, simpulan, evaluasi, dan formatif. Modul Ketiga "Atomisme Logis Bertrand Russel" terdiri dari sub pokok bahasan: Atomisme Logis, Prinsip Kesesuaian Bertrand Russel, Struktur Proposisi Bertrand Russel, Kelemahan Teori Bertrand Russel, simpulan, evaluasi, dan formatif. Modul Keempat "Atomisme Logis Wittgenstein" terdiri dari; pemikiran Wittgenstein I, pemikiran Wittgenstein II, permainan bahasa dalam pembelajaran, serta kelemahan dari pemikiran Wittgenstein. Modul Kelima "Positivisme Logis Alfred Jules Ayer" yang membahas tentang: positivisme logis, Alfred Jules Ayer, positivisme Alfred Jules Ayer, kritik positivisme Alfred Jules Ayer, simpulan, evaluasi, dan formatif.

Desain modul dalam tabel 2 di atas masih memerlukan proses refisi setelah dilakukan proses uji desain modul. Langkah ini masuk kegiatan refisi dan desain modul filsafat bahasa. Draf modul yang telah dikelompokan tiap modul digandakan dan selanjutnya akan dibagikan di kelas sebagai sumber belajar mahasiswa pada mata kuliah filsafat bahasa. Terdapat 9 modul namun tidak seluruhnya di uji dengan pertimbangan jumlah pertemuan 14 kali pertemuan dengan waktu 90 menit.

Draf modul "filsafat bahasa dalam scientific berbasis pendidikan karakter" masih memerlukan pengaturan urutan materi/ topik secara logis dalam upaya membantu peserta mahasiswa menyerap materi pelajaran disajikan. Proses pembelajaran yang dilakukan selama 14 kali pertemuan jadikan pengalaman mahasiswa sebagai titik awal, dan didasarkan pada kebutuhan mahasiswa, bukan didasarkan pada gagasan peneliti semata. Menguraikan materi bergerak dari yang sederhana menuju pada yang lebih kompleks, pada setiap unit atau penggalan materi (kegiatan per topik meteri kuliah) diberikan kegiatan belajar. Kegiatan belajar seharusnya mahasiswa diberikan kesempatan mempraktekkan khususnya berkaitan dengan kemampuan berpikir kritis dan logis sebelum melangkah pada pembelajaran materi selanjutnya. Formatif sebagai instrumen bagi mahasiswa apakah menguasai materi pada kegiatan belajar sebelum melanjutkan pada kegiatan belajar selanjutnya.

Pertimbangan dalam mengatur urutan materi, coba perhatikan: 1) tingkat kesulitan materi yang akan disajikan sesuai dengan kemampuan mahasiswa, 2) materi filsafat bahasa yang berhubungan dengan teori baru harus disampaikan secara hatihati dan cermat, 3) kejelasan dari aktivitas kegiatan pembelajaran yang dilakukan 
mahasiswa apakah sudakh sesuai dengan kompetensi yang diharapkan dan kegiatan pembelajaran yang harus dilakukan, 4) penggunaan media pembelajaran seperti LCD, HDMI ataupun audio visual lainnya sudah.

Berdasarkan hasil analisis selama kegiatan belajar di kelas selama 14 kali pertemuan modul 'Filsafat bahasa dalam Scientfific Berbasis Nilai karakter Jilid 1 dan 2 masih banyak memerlukan proses refisi terutama berkaitan dengan waktu yang diperlukan dalam mempelajari setiai kegiatan belajar. Tabel 2 dijadikan landasan dalam penyusunan draf modul seperti terlihat dalam tabel 3 dan 4. Modul disusun secara kronologis dan saling berhubungan sehingga masih terpisah-pisah antara kegiatan belajar pertama dengan kegiatan belajar selanjutnya. Untuk itu masih memerlukan proses refisi draf yang terlihat dalam tabel 1 dan 2 di atas belum dapat mencapai kompetensi yang diinginkan disebbkan kegiatan belajar dan evaluasinya belum begitu baik.

Proses umpan balik melibatkan merevisi instruksi berdasarkan data yang dikumpulkan selama tahap implementasi modul. Jika, selama fase ini, dosen menemukan bahwa mahasiswa tidak belajar tidak sesuai dengan apa rencanakankarena tidak sesuai dengan keinginan mahasiswa, atau mereka tidak menikmati proses pembelajaran, guru akan mencoba untuk merevisi dan memperbaiki beberapa aspek dari instruksi mereka untuk memungkinkan mahasiswa untuk mencapai tujuan mereka. Dalam penelitian dengan judul Design And Development Of Physics Module Based On Learning Style And Appropriate Technology By Employing Isman Instructional Design, proses refisi instruksi sesuai dengan komentar guru dan siswa (Alias, N \& Siraj, S, 2012, p. 84). Pada proses pengambangan modul tahun pertama peneliti melakukan refisi desain modul filsafat bahasa berdasarkan masukan dari dosen dan mahasiswa pada proses pembelajaran yang menggunakan modul filsafat bahasa.

\section{Pengembangan Modul Tahun Kedua}

Tahapan penelitian untuk tahun kedua terdiri dari beberapa tahapan; tahap pertama, validasi ahli dan respon mahasiswa, tahap kedua refisi, tahap ketiga uji coba secara terbatas, tahap keempat refisi, tahap kelima uji coba secara luas, dan tahap keenam modul sudah dapat diproduksi secara masal. Sebelum pada tahap validasi ahli peneliti melakukan kegiatan refisi draf modul tersebut selama 2 bulan untuk mengelompokan materi yang relefan dengan setiap kegiatan belajar berdasarkan catatan baik dari masukan dosen pengampu maupun mahasiswa sebagai subyek penelitian.

Menurut Sudarwati (2013, p. 115), yang diperlukan dalam pengembangan modul di antaranya: pengembangan modul harus terjalin kerjasama antara guru atau fasilitator; peserta didik, dunia usaha, dan peneliti dalam mementukan: 1) analisis kebutuhan materi apa yang akan diajarkan yang disesuaikan dengan kondisi pembelajaran terlebih dahulu kita lakukan observasi langsung berdasarkan tingkat kebutuhan siswa terhadap materi yang akan diajarkan disesuaikan dengan pengguna, peserta didik yang didasarkan dari modul sebelumnya;2) pengembangan modul ini dilakukan melalui komunikasi dan diskusi antara guru, fasilitator, peserta didik, dan dunia usaha dan industri; 3) Tahap validasi modul guru, fasilitator, peserta didik, dan dunia usaha dan industri; 4) pengembangan modul didasarkan dari penilaian dari ahli pembelajaran, ahli modul untuk melihat kualitas modul dan efektifitas modul dalam meningkatkan kemampuan produktif dan kemampuan berbahasa.

Draf modul pada tabel 3 tersebut masih memerlukan uji coba 3 kali, sebagai bahan revisi. Uji coba dengan menggunakan draf tersebut untuk mendapatkan komentar atau catatan dari mahasiswa dan dosen. Adapun yang perlu mendapatkan refisi terutama pada urutan kronologis 
materi dalam setiap kegiatan belajar yang berhubungan dengan tujuan / kompetensi, evaluasi, dan judul modul. sebuah draf modul dan judul draf modul berbeda.

Draf desain modul Filsafat Bahasa Scientific Berbasis Nilai Kearifan Lokal Jilid II dapat dilihat dalam tabel 4. Desain modul tersebut terdiri dari empat modul, untuk tiap modul terdiri dari bagian; pertama kompetensi; kedua kegiatan belajar, dan ketiga materi. Modul pertama "Filsafat Bahasa dan Kekinian", modul kedua "Hakikat Bahasa dan Ilmu Pengetahuan, modul ketiga "Filsafat Analitik Bahasa", dan modul keempat "Positivisme Logis Bahasa", daftar pustaka, glosarium, dan tentang penulis. Judul sudah sesuai dengan judul tiap bagian modul. Sedangkan materi dan kegiatan belajar kami susun dengan sistematis untuk memudahkan pencapaian berpikir kritis mahasiswa meningkat dengan komptensi berbahasa yang meningkat. Kesesuaian antara komponen pembentuk modul memerlukan proses kajian yang mendalam sehingga dapat menyusun modul seperti terlihat dalam tabel 3 .

\section{Tabel 3. Filsafat Bahasa Scientific Berbasis Nilai Kearifan Lokal Jilid I}

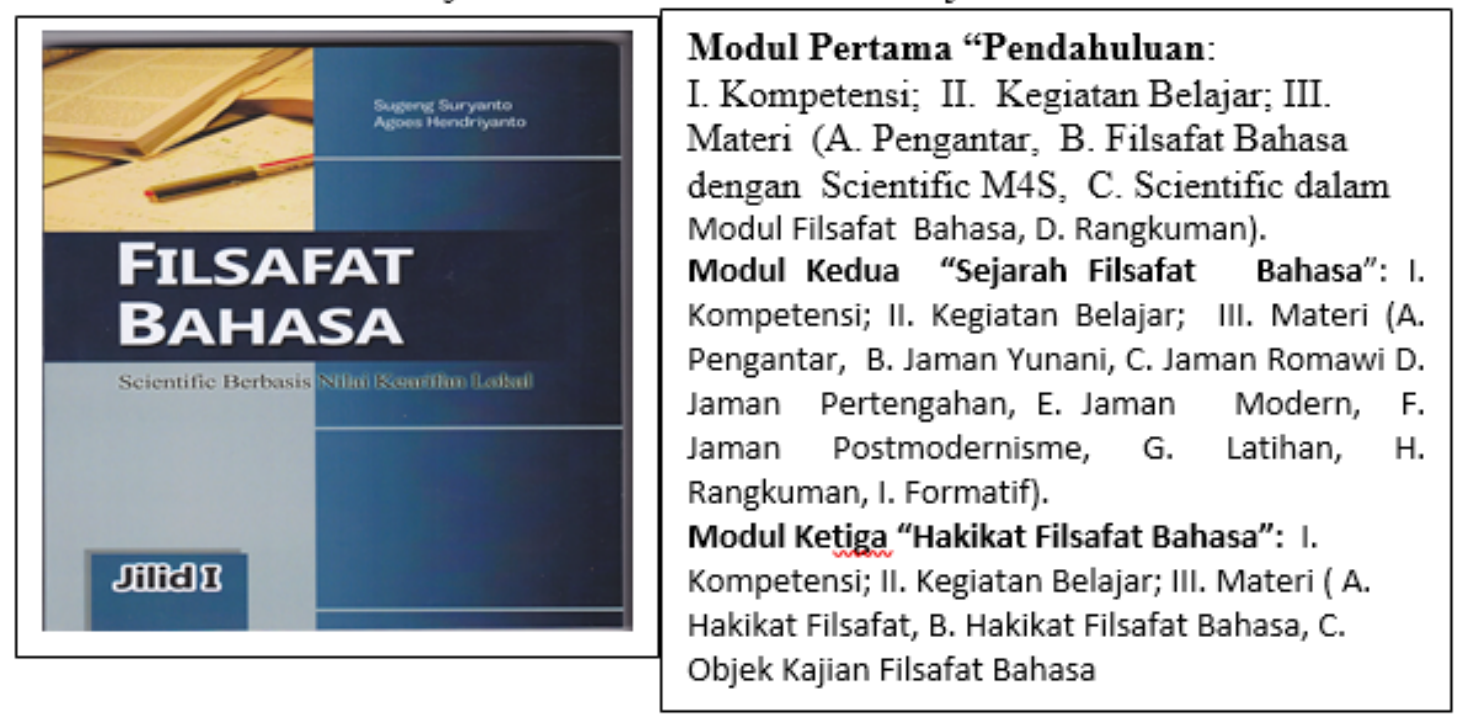

D. Manfaat Filsafat Bahasa, E. Peranan Filsafat Bahasa, F. Nilai Kearifan Lokal, G. Latihan, H.Rangkuman, Tes Formatif.

Modul Keempat "Bidang Kajian Filsafat Bahasa" : I. Kompetensi; II. Kegiatan Belajar; III. Materi (A.Bidang Kajian Filsafat Bahasa, B. Metafisika Filsafat Bahasa, C. Ontologi Filsafat Bahasa, D. Metode dalam Ontologi Filsafat Bahasa, E. Epistemologi Filsafat Bahasa, F. Bahasa Sebagai Media Berpikir Manusia, G. Pengetahuan Bahasa, H. Aksiologi Filsafat Bahasa, I. Kesesatan dalam Filsafat Bahasa, J. Kebenaran dalam Filsafat Bahasa, K. Latihan, L. Rangkuman, M. Tes Formatif.

Kunci Jawaban Tes Formatif, Daftar Pustaka, Glosarium

Desain modul filsafat bahasa scientific jilid 1 dan 2 masih memerlukan tahap validasi draf modul "Filsafat Bahasa Scientific Berbasis Nilai Kearifan Lokal" dengan melakukan kegiatan uji dengan angket respon mahasiswa terhadap modul filsafat bahasa scientific . dari hasil angket respon mahasiswa tersebut didapatkan respon mahasiswa 80,2 \%. Hasil angket respon mahasiswa peneliti gunakan sebagai bahan untuk merefisi kembali modul filsafat bahasa tersebut. Adapun jawaban angket mahasiswa yang mendapatkan jawaban rendah disebabkan sebagai berikut, modul belum disusun secara kronologis sehingga membuat mahasiswa untuk sulit dalam memahami materi filsafat bahasa. Selain itu modul kurang menarik karena tulisannya 
tidak begitu jelas sehingga akan menggurangi daya tarik mahasiswa untuk membacanya. Ejaannya terutama dalam kutipan masih banyak yang keliru dan penggunaan tanda miring pada huruf asing masih terlihat kesalahan penulis. Hasil dari respon angket mahasiswa peneliti gunakan sebagai refisi draf modul "Filsafat Bahasa Scientific Berbasis Nilai Kearifan Lokal".

Setelah proses refisi selesai peneliti melakukan uji validasi ahli dari Universitas Negeri Surakarta dan STKIP PGRI Ponorogo untuk menilai kelayakan modul yang peneliti kembangkan. Hasil kelayakan modul diukur dari hasil penilaian validator ahli yang terdiri atas dua ahli materi dan dua ahli bahasa, kelayakan modul juga dapat diukur melalui hasil uji coba terbatas melalui angket respons siswa.

Validasi modul berkaitan dengan: pertama struktur modul (cover, kata pengantar, daftar isi, kompetensi, kegiatan pembelajaran, organisasi penyajian umum, tampilan umum menarik, keterkaitan yang konsisten antara materi; kedua, organisasi penulisan materi (cakupan materi, kejelasan dan urutan materi, ketepatan materi dengan SK, keterkaitan antara masalah dengan konteks kehidupan / kognisi siswa yang termuat dalam modul; dan ketiga bahasa (penggunaan bahasa sesuai dengan EYD, bahasa yang digunakan komunikatif, kesederhanaan struktur kalimat). Hasil validasi ahli modul mendapatkan skor $89 \%$ layak digunakan untuk pembelajaran.
Berdasarkan hasil validasi ahli aspek penilaiannya ejaan yang masih banyak terjadi kesalahan bahasa tidak sesuai dengan EYD. Peneliti melakukan refisi berkaitan dengan penulisan tanda baca, kata asing yang harus dimiringkan, dan cara pengutipan. Struktur modul sudah cukup baik yang terdiri dari cover, kata pengantar, daftar isi, kompetensi, kegiatan pembelajaran, organisasi penyajian, tampilan modul, keterkaitan antar materi. Selain itu juga organisasi penulisan materi sudah cukup baik yang meliputi; cakupan materi, kejelasan materi, keterkaitan materi dengan kompetensi, keterkaitan materi dengan konteks.

Tahapan ketiga adalah tahap uji coba terbatas dengan eksperimen single one shot study dengan membandingkan hasil ratarata skor mahasiswa dari uji coba pertama dengan kedua, uji coba pertama dengan uji coba ketiga, uji coba pertama dan keempat, uji coba kedua dan uji coba ketiga, uji coba kedua dan keempat, dan uji coba ketiga dan keempat. Langkah terakhir dalam pengembangan modul uji coba dalam proses pembelajaran melibatkan belajar penuh, guru ingin memastikan bahwa siswa mereka telah belajar apa rencana instruksional ingin mereka belajar dilakukan pra / post test dilakukan untuk menguji efektivitas modul (Alias, Norlidah Alias \& Siraj, S, 2012:88). Proses selanjutnya dengan uji coba terbatas modul dengan menggunakan metode eksperimen single one shot case study dalam pembelajaran filsafat bahasa. 
Tabel 4. Filsafat Bahasa Scientific Berbasis Nilai Kearifan Lokal Jilid II

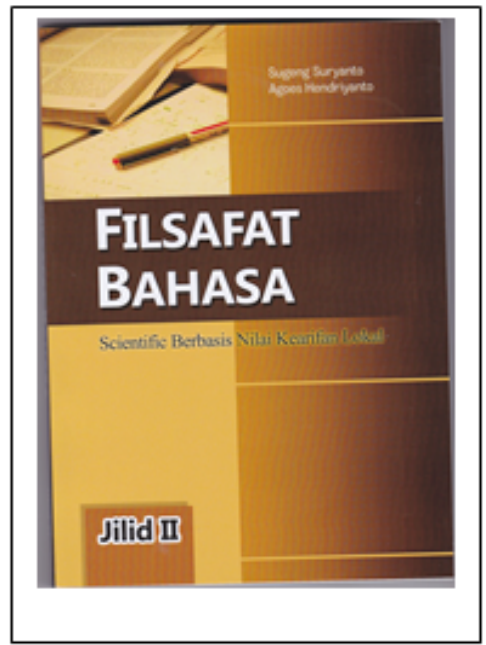

Modul Pertama: "Filsafat Bahasa dan Kekinian"; I. Kompetensi; II. Kegiatan Belajar; III. Materi (A. Filsafat , B. Bahasa dalam Perkembangan Peradaban, C. Perkembangan Pemikiran Manusia, D. Filsafat Bahasa dan Kekinian, E. Filsafat Bahasa dalam IImu engetahuan, F. Peran Filsafat bahasa dalam IImu Pengetahuan, G. Postmodernisme Fisafat Bahasa, $\mathrm{H}$. Perubahan Sosial dalam Masyarakat, I. Tantangan Kekinian, J. Kemajuan Ilmu Pengetahuan dan Teknologi, K. Latihan, L. Rangkuman, M. Formatif

Modul Kedua "Hakikat Bahasa dan IImu Pengetahuan"; I. Kompetensi; II. Kegiatan Belajar; III. Materi (A. Hakikat Bahasa, B. Bahasa dan Globalisasi, C. Budaya dan Bahasa,

D. Makna Bahasa, E. Hakikat Bahasa dan Manusia, F. Bahasa dan Nilai Kearifan Lokal, G. Modernitas dan Nilai Kearifan Lokal, H. Bahasa Indonesia sebagai Bahasa Ilmu Pengetahuan, I. Bahasa Sebagai Alat Komunikasi, J. Kualitas Sumber Daya Manusia Indonesia, K. Globalisasi dan Radikalisme, L. Latihan, M. Rangkuman, N. Formatif.

Modul Ketiga "Filsafat Analitik Bahasa": I. Kompetensi; II. Kegiatan Belajar, III. Materi (A. Filsafat Analitik Bahasa, B. Filsafat Analitik Bahasa, C. Perkembangan Filsafat Analitika Bahasa, D. Filsafat Bahasa Biasa (The Ordinary Language Philosophy), E. Atomisme Logis Bertrand Russel, F. Atomisme Logis Wittgenstein, G. Latihan ，H. Rangkuman, I. Tes Formatif.

Modul Keempat "Positivisme Logis Bahasa": I. Kompetensi; II. Kegiatan Belajar; III. Materi (A. Positivisme Logis, B. Logika Matematika dan Bahasa, C. Emprisme Filsafat Bahasa, D. Logika dan Positivisme, E. Strukturalisme Ferdinand De Saussure ...., F. Latihan, G. Rangkuman, H. Formatif Kunci Jawaban Tes Formatif, Daftar Pustaka, Glosarium

\section{SIMPULAN}

Uji coba secara terbatas dengan pre test dan post test digunakan untuk uji t. Berdasarkan tabel 5 menghasilkan $t_{\text {hitung }}$ sebagai berikut $\left(\mathrm{t}_{12}=2,77, \mathrm{t}_{13}=7,89, \mathrm{t}_{14}=8,96, \mathrm{t} 23=2,88, \mathrm{t}_{24}\right.$ $\left.=4,69, \mathrm{t}_{34}=2,79\right)$ lebih besar dari $\mathrm{t}_{\text {tabel }}$ dengan derajat bebas 38 (2,021). Kesimpulannya Ho diterima bahwa modul filsafat bahasa scientific berbasis nilai kearifan lokal dan filsafat bahasa kekinian layak digunakan untuk kegiatan pembelajaran pada mata kuliah filsafat bahasa di Jurusan Bahasa dan Sastra Indonesia. 
54 Jurnal Pendidikan Bahasa dan Sastra, Volume 17, Nomor 1, April 2017, blm. 41-56

Tabel 5. Data hasil uji coba terbatas dengan tingkat kesalahan 5\% derajat bebas 38

\begin{tabular}{|c|c|c|c|c|c|}
\hline Kegiatan & $\underset{\mathrm{n}}{\text { Jumlah }}$ & $\begin{array}{c}\mathrm{X} \\
\text { Rata-rata }\end{array}$ & $\begin{array}{l}\text { Standar } \\
\text { Deviasi }\end{array}$ & $\begin{array}{l}\text { Standar } \\
\text { Deviasi }\end{array}$ & Hitung \\
\hline UC 1 & 20 & 11,16 & 1,56 & & \\
\hline UC 2 & 20 & 13,05 & 2,43 & 2,04 & 2,94 \\
\hline UC 1 & 20 & 11,16 & 1,56 & & \\
\hline UC 3 & 20 & 14,85 & 1,41 & 1,48 & 7,89 \\
\hline UC 1 & 20 & 11,16 & 1,56 & & \\
\hline UC 4 & 20 & 16,45 & 2,14 & 1,87 & 8,96 \\
\hline $\mathrm{UC} 2$ & 20 & 13,05 & 2,43 & & \\
\hline $\mathrm{UC} 3$ & 20 & 14,85 & 1,41 & 2,98 & 2,88 \\
\hline UC 2 & 20 & 13,05 & 2,43 & & \\
\hline $\mathrm{UC} 4$ & 20 & 16,45 & 2,14 & 2,29 & 4,69 \\
\hline $\mathrm{UC} 3$ & 20 & 14,85 & 1,41 & & \\
\hline UC 4 & 20 & 16,45 & 2,14 & 1,81 & 2,79 \\
\hline
\end{tabular}

Keterangan: UC $=$ uji coba

Berdasarkan uji coba terbatas dapat uji coba secara lebih luas di STKIP PGRI disimpulkan bahwa modul "Filsafat bahasa Scientific Berbasis Nilai Kearifan Lokal Jilid I dan II" layak digunakan dalam cakupan mahasiswa STKIP PGRI Pacitan. Untuk menguji kelayakan modul peneliti lakukan Ponorogo menggunakan eksperimen one group pretest-postest suatu penelitian eksperimen yang hanya membandingkan: hasil awal yang dibandingkan dengan hasil kedua, hasil ketiga, dan seterusnya.

Tabel 6. Data hasil uji coba luas dengan tingkat kesalahan 5\% derajat bebas 38

\begin{tabular}{|c|c|c|c|c|c|}
\hline Kegiatan & $\begin{array}{c}\text { Rata- } \\
\text { rata }\end{array}$ & $\begin{array}{c}\text { Standar } \\
\text { deviasi }\end{array}$ & $\begin{array}{l}\text { Standar } \\
\text { Deviasi }\end{array}$ & $\begin{array}{c}\mathrm{T} \\
\text { Hitumg }\end{array}$ & $\begin{array}{c}\mathrm{T} \\
\text { Tabel }\end{array}$ \\
\hline UC 5 & 11,18 & 2,198 & & & \\
\hline UC 6 & 13,45 & 2,987 & 2,622 & 2,766 & 2,021 \\
\hline UC 5 & 11,16 & 2,198 & & & \\
\hline UC 7 & 15,35 & 2,212 & 2,046 & 6,481 & 2,021 \\
\hline UC 6 & 13,45 & 2,987 & \multirow{2}{*}{2,628} & \multirow{2}{*}{2,288} & \multirow{2}{*}{2,021} \\
\hline UC 7 & 15,35 & 2,212 & & & \\
\hline
\end{tabular}

\section{Keterangan: UC $=u j i$ coba}

Tahap selanjutnya dengan melakukan tahapan penelitian pengembangan dengan melakukan uji coba secara luas degan menggunakan eksperimen one group pretest-postest. Peneliti melakukan 3 kali uji coba untuk mendapatkan hasil kompetensi mahasiswa dengan mengerjakan evaluasi dalam setiap modul. Hasil dari evaluasi tersebut harus didiskusikan didepan kelas untuk melihat kompetensi berbicara mahasiswa. Walaupun dijawaban tertulis mahasiswa sederhana bahkan hanya beberapa kalimat dapat dikembangkan dengan baik pada saat diskusi di kelas.

Nilai rata-rata uji coba 4, 5, dan 6 dapat digunakan untuk memperoleh standar deviasi masing-masing dianalisis dengan uji tdapaun hasil uji t dapat dilihat dalam tabel 6. Berdasarkan tabel 6 di atas kita bandingkan antara uji coba 5 dan 6 , untuk nilai rata-rata 
uji coba $6(13,45)$ lebih besar dari ujicoba 5 $(11,18)$. Pengujian signifikeansi diperoleh $t_{\text {hitung }}$ 2,77 lebih besar dari $t_{\text {tabel }}$ 2,021. Dengan demikian perbedaan hasil uji coba 5 dan 6 signifikan. Modul filsafat bahasa efektif digunakan karena dapat meningkatkan kompetensi pada uji coba 5 dan 6 . Berdasarkan hasil uji coba secara luas hasil uji t menghasilkan t hitung lebih besar ( $\mathrm{t} 56=$ $2,77, \mathrm{t}_{57}=6,48$, dan $\left.\mathrm{t}_{67}=2,29\right)$ lebih besar dari $\mathrm{t}_{\text {tabel }}(38,0,05)$ sebesar 2,021 . Kesimpulannya Ho diterima mengandung arti bahwa modul filsafat bahasa scientific berbasis nilai kearifan lokal jilid I dan II layak digunakan untuk kegiatan pembelajaran pada mata kuliah filsafat bahasa di Jurusan Bahasa dan Sastra Indonesia Perguruan Tinggi. Berdasarkan simpulan di atas modul dicetak menjadi 2 jilid sebagai berikut; Modul Filsafat Bahasa Scientific Berbasis Nilai Kearifan Lokal jilid I dengan ISBN 978-602-25829-3-3 dan jilid II ISBN 978-602-25829-3-4.

\section{SIMPULAN}

Pengembangan modul filsafat bahasa dengan menggunakan metode penelitian pengembangan dibagimenjadi 2 tahun. Untuk tahun pertama terdiri dari 3 tahapan yang terdiri dari; potensi dan permaslahan yang muncul, pengumpulan data yang berkaitan dengan materi ataupun pembelajaran filsafat bahasa, tahap ketiga melakukan kegiatan refisi draf modul. Untuk penelitian tahun pertama peneliti mendapatkan bahanbahan refensi baik dari pakar filsafat bahasa maupun pakar bahasa, studi literatur, catatan pada saat kegiatan pembelajaran di kelas, sumber media, dan kompetensi mahasiswa yang ingin dicapai.

Tahap selanjutnya peneliti melakukan uji terbatas dengan menggunakan metode eksperimen single one shot case study. Uji coba secara terbatas hasil uji t menghasilkan $t_{\text {hitung }}$ $\left(\mathrm{t}_{12}=2,77, \mathrm{t}_{13}=7,89, \mathrm{t}_{14}=8,96, \mathrm{t}_{23}=2,88, \mathrm{t}_{24}\right.$ $\left.=4,69, t_{34}=2,79\right)$ lebih besar dari $t_{\text {tabel }}$ dengan derajat bebas 38 (2,021). Kesimpulannya Ho diterima mengandung pengertian bahwa modul filsafat bahasa scientific berbasis nilai kearifan lokal jilid I dan II layak digunakan untuk kegiatan pembelajaran pada mata kuliah filsafat bahasa di Jurusan Bahasa dan Sastra Indonesia.

Uji coba pemakaian uji secara luas menggunakan eksperimen one group pretestpostest. Uji coba secara luas hasil uji $\mathrm{t}$ menghasilkan $t_{\text {hitung }}$ lebih besar $\left(t_{56}=2,77, t_{57}\right.$ $=6,48$, dan $\left.\mathrm{t}_{67}=2,29\right)$ lebih besar dari $\mathrm{t}_{\text {tabel }}$ $(38,0,05)$ sebesar 2,021. Kesimpulannya Ho diterima mengandung arti bahwa modul filsafat bahasa scientific berbasis nilai kearifan lokal jilid I dan II layak digunakan untuk kegiatan pembelajaran pada mata kuliah filsafat bahasa di Jurusan Bahasa dan Sastra Indonesia Perguruan Tinggi

\section{DAFTAR RUJUKAN}

Alias, N \& Siraj, S. (2012). Design and development of physics module based on learning style and appropriate technology by employing Isman Instructional Design Model. TOJET: The Turkish Online Journal of Educational Technology - October 2012, volume 11 Issue 4. Pp. 84-94

Biggs, J. (1999). Teaching for Quality Learning at University. Buckingham: SRHE/ OU Press

Depdiknas. (2002). Kurikulum Inti nomor 45. Jakarta Indonesia: Kementerian Pendidikan dan Kebudayaan Republik Indonesia.

Donnelly, R and Fitzmaurice, M. (2005). Designing Modules For Learning. In: Emerging Issues in the Practice of University Learning and Teaching. O’Neill, G., Moore, S., McMullin, B. (Eds). Dublin:AISHE, Released under Creative Commons licence: Attribution-NonCommercial 2.0. Some rights reserved.http: //www. aishe.org / readings/2005-1/

Ormrod, J.E. (2008). Psikologi Pendidikan. (Jilid I). Jakarta: Penerbit Erlangga 
56 Jurnal Pendidikan Bahasa dan Sastra, Volume 17, Nomor 1, April 2017, blm. 41-56

Erton, I. (2007). "Applied Pragmatics and Competence Relations in Language Learning and Teaching". Journal of Language and Linguistic Studies Volume 3, Nomor, April 2007.

Hashimah, M., Yunus, Z. I., \& Raper, G. (2007). Malaysian Primary Teachers' Classroom Practice of Teaching and Learning Science. Journal of Science and Mathematics Education, Volume 27(1). http://dx.doi.org/10.1080 /17439880701511040

Kemdikbud. (2014). Peraturan Menteri Pendidikan dan Kebudayaan Republik Indonesia nomor 49 tahun 2014 tentang Standar Nasional Pendidikan Tinggi. Jakarta Indonesia: Kementerian Pendidikan dan Kebudayaan Republik Indonesia.

Nurgiyantoro, B. (2010). Penilaian Pembelajaran Bahasa Berbasis Kompetensi. Yogyakarta: BPFE Yogyakarta.

Purwanto, A.R., \& Suharto L. (2007). Pengembangan Modul. Jakarta: Pustekom

Richards, J.J. (2010). "Competence and Performance in Language Teaching". RELC Journal August. Volume 41, Nomor 2, pp. 101-122.

Santyasa, I.W.(2009). Metode Penelitian Pengembangan dan Teori Pengembangan Modul.
Diunduh 17 Oktober 2016, dari http://santyasa.blogspot. com/2009/01/metode-penelitianpengembangan-html

Sudarwati, N. (2013). Developing an Integrated Module on Entrepreneurship to Improve Ability in Making Business Plans. International Journal of Business, Humanities and Technology. Volume 3 Nomer 5 May 2013.pp. 115

Suryanto, S., \& Hendriyanto, A. (2015). Filsafat Bahasa Dalam Scientific Berbasis Pendidikan Karakter Jilid 1 \& 2. Surakarta: Yuma Pustaka.

Suryanto, S., \& Hendriyanto, A.. (2016). Filsafat Bahasa Scientific Berbasis Nilai Kearifan Lokal Jilid 1 \& 2. Lamongan: Pustaka Ilalang.

Wena, M. (2010). Strategi Pembelajaran Inovatif Kontemporer: Suatu Tinjauan Konseptual Operasional. Jakarta: Bumi Aksara.

\section{UCAPAN TERIMA KASIH}

Ucapan terima kasih disampaikan kepada Direktorat Riset dan Pengabdian Masyarakat Direktorat Jendral Penguatan Riset dan Pengembangan Kementerian Riset, Teknologi dan Pendidikan Tinggi yang telah mendanai penelitian ini. 